\title{
Note
}

\section{Epiphytic Zoobenthos on Bryophyte Mats in a Cool Mountain Stream, Toyamazawa}

\author{
Mitsuru Tada and Ken'ichi Satake
}

\begin{abstract}
Quantitative samples of benthic macroinvertebrates were taken in November 1989 , May and September 1990 from the mats of bryophyte (Rhynchostegium riparioides) and bare rock bottom at upper reaches of a cool mountain stream, Toyamazawa in Nikko National Park, central Japan. Numbers of taxa confirmed by the study were low, 11 -13 and 13-14 on bryophyte mats and bare rock bottom, respectively. The overall abundance of macroinvertebrates in bryophyte areas was much higher than that in bare rock areas. Micrasema sp. MC was the most abundant taxon on bryophyte mats, and the density on the mats exceeded 100,000 individuals $\mathrm{m}^{-2}$ in November 1989. The abundance of Micrasema sp. MC on bryophyte mats was 2.8-16.3 times higher than that on bare rock bottom. The second and the final instar larvae of Micrasema sp. MC on the mats were significantly more abundant than those at bare rock bottom on almost all sampling occasions.
\end{abstract}

Key words : macroinvertebrate, bryophyte mat, bare rock bottom, Micrasema

In headwater streams and flows, the mats of bryophytes (liverworts and mosses) are sometimes prominent on large boulders and bedrock. Although living bryophytes are seldom eaten by animals, often small invertebrates (mites, nematodes, small crustaceans and chironomid larvae) are commonly associated with them (GERson, 1982). They feed on fine detritus trapped by bryophytes and on periphytic diatoms that grow on living fronds (MAURER and BRUSVEN, 1983; WINTERBOURN and TOWNSEND, 1991).

Invertebrate density is greater on bryophytes than on bare rocks (e.g. Mc ELHONE and DAVIES, 1983 ; Brusven et al., 1990; SuREN, 1991), whereas species abundance on bryophytes is not so different from that on bare rocks (HYNES, 1961 ; Egglishaw, 1969).

There have been a few investigations of invertebrate assemblages associated with bryophytes in Japanese streams. TsudA (1940) revealed that Micrasema spp. were dominant taxa on moss mats of some mountain streams in Kyoto. Iто $(1986,1988,1991)$ reported that the larvae of Palaeagapetus (Trichoptera, Hydroptilidae) lived and fed on leaves of liverwort (Chiloscyphus polyanthos, Lophocoleaceae) and made cases of the leaf pieces. But there is no study to compare the fauna between bryophyte mats and bare rock bottom within the same stream reach. Thus we conducted the present study at the upper reaches of a mountain stream, Toyamazawa, in central Japan to compare macroinvertebrate fauna between these two habitat types.

Study site. Toyamazawa is a small stream located approximately $17 \mathrm{~km}$ west of Nikko City in Tochigi Prefecture, central Japan $\left(36^{\circ} 45^{\prime}\right.$ $\mathrm{N}, 139^{\circ} 25^{\prime} \mathrm{E}$ ). It flows about $6.6 \mathrm{~km}$ from the source (altitude: $1,700 \mathrm{~m}$ ) to Lake Chuzenji (altitude: $1,200 \mathrm{~m}$ ). The stream was 3 to $5 \mathrm{~m}$ wide, and the bottom was mainly covered with cobbles (64-256 mm) and sands (0.0625-2 mm). Since the stream is located in the Nikko 
National Park, comping, fishing and hunting are forbidden. There are no permanent dwellings nor sewage sources in the watershed.

This study was carried out at the upper reaches of the stream (Fig. 1). The study site was about $30 \mathrm{~m}^{2}$ (10 m length and $3 \mathrm{~m}$ width) in area and was located about $10 \mathrm{~m}$ downstream of a spring. An aquatic moss species, Rhynchostegium riparioides (Hypnobryales: Brachytheciaceae) was abundant on bedrock and cobbles, covering $10-30 \%$ of bottom area at the study site.

Methods. Water temperature, specific conductivity and $\mathrm{pH}$ were measured monthly by a portable conductivity meter (SC-51, Yokogawa Electric Works, Japan) and a $\mathrm{pH}$ meter ( $\mathrm{pH}-81$, ditto) at the upper part of the study site between 10: 00 and 11: 00 am from November, 1989 to October, 1990.

Macroinvertebrates were collected from a riffle area at the study site on 29 November, 1989, and 24 May and 10 September, 1990. Three samples were taken each from bare rock bottom and bryophyte mats, using a box type Surber sampler (Rigosha, Japan) (area of quadrate : $25 \mathrm{~cm} \times 25 \mathrm{~cm}$, mesh size of the net: 0.1 $\mathrm{mm})$. At bare rock bottom, all the stones within the quadrate were picked up and the attached material was washed into the net by hand. At bryophyte mats, all the bryophyte-covered cobbles $(64-256 \mathrm{~mm})$ within the quadrate were picked up by hand or shovel and the attached material on the bryophytes was washed out into

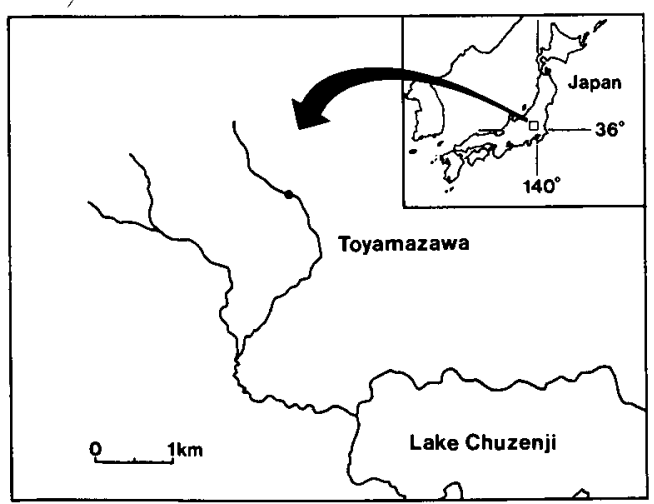

Fig. 1. Location of the study site in the stream, Toyamazawa in central Japan. the sampler by hand. Each sample of material and the cobbles were preserved in $10 \%$ formalin.

Stones and mineral fragments were removed from the material by elutriation in the laboratory. The bryophytes were examined visually and the remaining macroinvertebrates were removed from the cobbles by handpicking under a binocular microscope $(\times 10$ magnification).

Macroinvertebrates were then hand-sorted under the same binocular microscope. Most aquatic insects were identified to genera or species, although parts of Tipulidae, Chironomidae, Simuliidae and small nymphs of Plecoptera were identified only to families or sub-families. Most identifications were performed using the keys in KaWAl (1990), and each taxon was then counted under a binocular microscope ( $\times 10-64$ magnification). The densities of each taxon on bryophyte mats and bare rock bottom were taken from the number of individuals per area of the sampler, and by the number of individuals per area of the bryophyte -covered cobbles, respectively. The area of the bryophyte-covered cobble was obtained by measuring projected area of cobble. The head capsule widths of Micrasema sp. MC larvae were measured to the nearest $0.01 \mathrm{~mm}$ under the same binocular microscope. The density of each taxon and that of each instar of Micrasema sp. MC larvae were statistically compared between bryophyte mats and bare rock bottom using the two-sample analysis of variance tests (T-, and G-test) (SoKal and RoHLF, 1981).

Physicochemical features. The water temperature at the study site was low and rather costant $\left(6.3-9.8^{\circ} \mathrm{C}\right)$.throughout the year. The water was not frozen even in winter because of a high discharge from a spring just upstream from the site. The $\mathrm{pH}$ was circum-neutral, ranging from 6.7 to 8.1 . The water was very clear except at high floods, and specific conductivity ranged between 25.3 and $36.1 \mu \mathrm{S} \cdot \mathrm{cm}^{-1}$.

Macroinvertebrates on bryophyte mats and bare rock bottom. The present study at Toyamazawa Stream yielded 20 taxa belonging to four orders from bryophyte mats, and 23 
Table 1. Mean macroinvertebrate density in bryophyte (Rhynchostegium riparioides) (B) and bare rock areas $(R)$ taken from the study site. Density at bare rock area was estimated on basis of river bed area but that in bryophyte was based on projected area of cobbles sampled.

\begin{tabular}{|c|c|c|c|c|c|c|}
\hline \multirow{3}{*}{ Taxon } & & & & \multicolumn{3}{|c|}{$10^{2}$ individuals $\mathrm{m}^{-2}$} \\
\hline & \multicolumn{2}{|c|}{ Nov. 1989} & \multicolumn{2}{|c|}{ May 1990} & \multicolumn{2}{|c|}{ Sep. 1990} \\
\hline & $\mathrm{B}$ & $\mathrm{R}$ & $\mathrm{B}$ & $\overline{\mathrm{R}}$ & $\mathrm{B}$ & $\mathrm{R}$ \\
\hline \multicolumn{7}{|l|}{ Ephemeroptera } \\
\hline Cinygmula spp.** & - & 2.7 & 0.1 & 1.4 & - & - \\
\hline Baetis thermicus* & 5.0 & 0.6 & 5.9 & 0.2 & 1.2 & 1.6 \\
\hline Drunella basalis** & 2.5 & 4.1 & 0.7 & 0.1 & 1.8 & 12.8 \\
\hline Ephemerella sp.* & 14.8 & 0.2 & - & - & 3.1 & 0.1 \\
\hline \multicolumn{7}{|l|}{ Plecoptera } \\
\hline Scopura sp.* & - & - & - & - & 0.4 & - \\
\hline Amphinemura spp.* & 1.7 & 0.2 & 7.8 & 0.5 & - & - \\
\hline Protonemura spp.* & - & 0.2 & 14.4 & 0.3 & 0.6 & 0.4 \\
\hline Megarcys ochracea & 3.3 & - & - & - & - & - \\
\hline Isoperla towadensis* & - & - & - & - & 0.6 & - \\
\hline Isoperla nipponica* & 4.1 & - & 5.9 & 0.3 & - & - \\
\hline Kamimuria tibialis** & - & 0.6 & - & - & - & - \\
\hline Acroneuria stigmatica** & - & - & - & 0.2 & - & 一 \\
\hline Perlidae ${ }^{* *}$ & - & - & - & - & - & 0.7 \\
\hline Chloroperlidae & - & 0.4 & - & - & 0.2 & - \\
\hline \multicolumn{7}{|l|}{ Trichoptera } \\
\hline Arctopsyche sp. & 2.5 & - & - & - & - & 0.6 \\
\hline Rhyacophila clemens & - & 0.1 & - & - & - & - \\
\hline Rhyacophila shikotsuensis & - & - & - & 一 & - & 0.3 \\
\hline Rhyacophila transquilla** & - & 4.4 & - & - & - & 0.5 \\
\hline Rhyacophila ?towadensis* & 1.7 & 1.1 & 2.6 & 1.1 & 0.2 & 0.3 \\
\hline Micrasema sp. MC* & 1018.2 & 62.6 & 624.8 & 39.3 & 26.1 & 9.3 \\
\hline Apatania sp.** & - & - & - & - & - & 1.3 \\
\hline Pseudostenophylax ondakensis* & 1.7 & - & - & - & - & - \\
\hline \multicolumn{7}{|l|}{ Diptera } \\
\hline Tipulinae & 0.4 & - & 0.2 & 0.1 & - & - \\
\hline Antocha spp.* & 1.3 & 0.1 & 7.0 & 0.6 & 0.4 & - \\
\hline Simuliidae* & - & - & 7.2 & 0.6 & - & 0.2 \\
\hline Tanypodinae ${ }^{*}$ & - & -- & 3.4 & 2.2 & - & - \\
\hline Diamesinae* & 0.3 & - & 5.6 & 3.8 & - & - \\
\hline Orthocladius spp.* & 2.2 & - & 218.5 & 13.2 & 0.6 & 0.3 \\
\hline Total & 1059.7 & 77.3 & 904.1 & 63.9 & 35.2 & 28.4 \\
\hline
\end{tabular}

taxa belonging to four orders from bare rock bottom (Table 1). Number of taxa at each sampling occasion was generally low, 11-13 and 13-14 on bare rock and bryophyte areas, respectively. All but the rarest taxa were common to both habitats.

Although the methods of sampling and den- sity estimation were different between the two habitat types, there were distinct differences in abundance of macroinvertebrates between them. The overall abundance of macroinvertebrates on bryophyte mats was 1.2-14.1 times higher than that on bare rock bottom (Table 1). Fifteen taxa, Baetis thermicus, Ephemerella sp., 
Scopura sp., Amphinemura, Protonemura, Isoperla towadensis, I. nipponica, Rhyacophila towadensis, Micrasema sp. MC, Pseudostenophylax ondakensis and five dipteran taxa were more abundant on bryophyte mats than on bare rock bottom ( $\mathrm{T}$-test, $\mathrm{P}<0.01$ ). Seven taxa, Cinygmula spp., Drunella basalis, Kamimuria tibialis, Acroneuria stigmatica, Perlidae, Rhyaco. phila transquilla and Apatania sp., were more abundant on bare rock bottom $(\mathrm{P}<0.01)$. Brusven et al. (1990) reported that insect densities were 4-18 times greater in moss clumps than on bare rock substrates adjacent to moss. This variance has often been attributed to an increase of surface area available for colonization (Harrod, 1964; Rooke, 1984 ; Minshall, 1984), and also to the fact that most of the invertebrates associated with bryophytes consumed trapped detritus and periphyton (SUREN, 1991).

Micrasema sp. MC was the most abundant macroinvertebrate at the site and more abun- dant on bryophyte mats than on bare rock bottom. The mean density on the mats exceeded 100,000 individuals $\mathrm{m}^{-2}$ in November 1989 (Table 1). The abundance of Micrasema sp. MC on bryophyte mats was 2.8-16.3 times higher than that on bare rock bottom. The species accounted for $69.1-96.1 \%$ of total individuals on bryophyte mats and $32.7-81.0 \%$ on bare rock bottom. McElhone and Davies (1983) and Tsuda (1940) also reported that the larvae of several Micrasema species were significantly more abundant on moss covered rocks than on bare rocks.

The size-frequency distributions of the head capsule width of Micrasema sp. MC larvae are shown in Figure 2. The second and final instar larvae of Micrasema sp. MC were more abundant on bryophyte mats than on bare rock bottom in November 1989 and September 1990 (G-test, $\mathrm{P}<0.01$ ), and November 1989 and May $1990(\mathrm{P}<0.01)$, respectively. But abundances of the third and fourth instar larvae were not

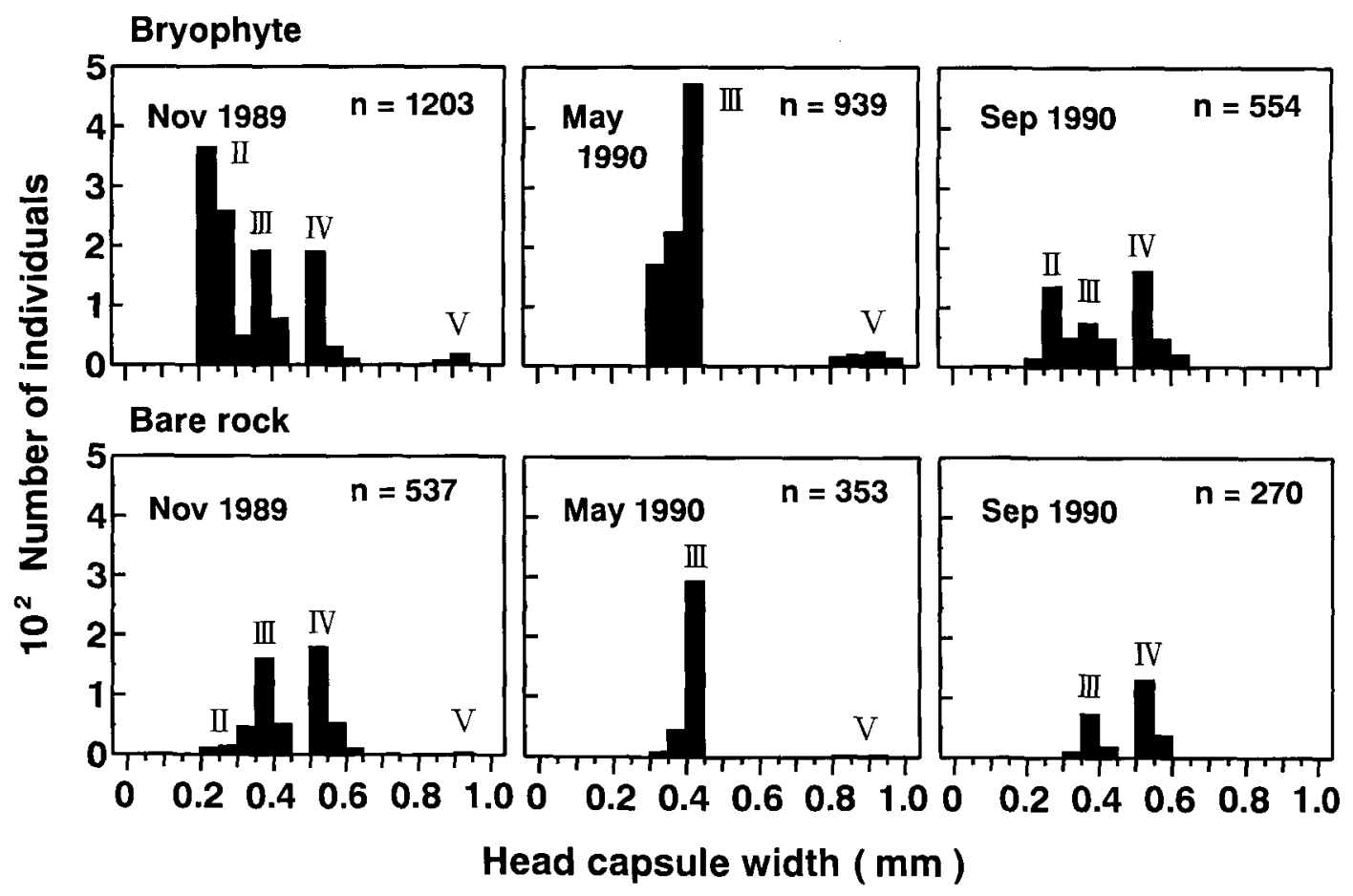

Fig. 2. Frequency distribution of head capsule width of Micrasema sp. MC on the mats of bryophyte (Rhynchostegium riparioides) and bare rock bottom at the study site in November 1989, and May and September 1990. Instars are designated based on the data by Kato (1992). 
significantly different between the two habitats $(\mathrm{P}>0.05)$. It can be supposed that bryophyte mats are available for oviposition sites by the adults and for the pre-pupal and pupal sites of Micrasema sp. MC.

Kato (1992) mentioned that the gut contents of second to fifth instar larvae of Micrasema sp. MC included the leaves of $R$. riparioides, and that first instar larvae made their cases of leaf pieces of the bryophyte The food habitat of Palaeagapetus rotundatus (Trichoptera: Hydroptilidae) was investigated by ITo (1991). The larvae feed on leaves of two species of liverworts (C. polyanthos and Scapania undulata), but do not feed on the leaves of $R$. riparioides.

Orthocladius (Diptera, Chironomidae) was the next most abundant taxon encountered on the bryophytes (24.2\% of total individuals) and on bare rock bottom (20.7\% of total individuals) in May 1990 in the present study (Table 1). TsuDA (1940) has already revealed that this genus was one of the dominant taxa on moss clumps in several mountain streams in Kyoto. Orthocladiinae was the most abundant taxon (61.1$78.8 \%$ of total number of animals) in moss samples from a Welsh mountain stream, and the pupae were also found from April through November in the samples (HyNEs, 1961).

With regard to other dipterans, the crane flies (Tipulidae) Dolichopeza, Liogma and Triogma lived in and fed on mosses (Gerson, 1982). Antocha (Tipulidae) and Simuliidae were also more abundant on bryophyte mats than on bare rocks (Táble 1).

\section{Acknowledgements}

We would like to acknowledge the valuable discussions with Dr. T. Iwakuma, National Institute for Environmental Studies. We are grateful to Mr. T. Nozaki, Kanagawa Environmental Research Center for the identification of $\mathrm{Mi}$ crasema larvae, as well as to Dr. M. HigucH, Hiroshima University for his identification of a moss species, Rhynchostegium riparioides. We thank Mr. R. Ueno, National Institute for Environmental Studies for his advice on the taxonomy of Chironomidae. Thanks are also due to staffs of the Local Forestry Office of Utsunomiya City, the Fishermen's Cooperative Association of Lake Chuzenji and the Nikko National-Park Custodian Office for their cooperation with our work within the park and in Toyamazawa stream.

\section{摘要}

\section{日光外山沢川上流部におけるコケに着生 の底生動物}

1989 年の 11 月と 1990 年の 5 月と 9 月に日光 国立公園内の外山沢川上流部でコケ（Rhynchostegium riparioides: アオハイゴケ) 上と石礫底 において底生動物の定量採集を行った。調查中に 採集された底生動物の幼虫の Taxa は両地点で 少なく,コケ中で 11ー13，れきで 13-14であった が，個体数は石碩底に比べコケ上で非常に多かっ た。Micrasema sp. MC(マルツツトビケラの一種) の幼虫は, 1989 年 11 月にコケ上で 100,000 個体 $\mathrm{m}^{-2}$ 以上の高密度で採集され，その密度はコケ上 で石䃯底に比べ 2.8-16.3 倍であった。また，そ の 2 令幼虫と終令幼虫は, 調查中のほとんどの採 集時においてコケ上で石礫底に比べその割合が有 意に高かった。

\section{References}

Brusven, M. A., W. R. Meeham and C. Biggamw (1990): The role of aquatic moss on community composition and drift of fish-food organisms. Hydrobiologia, $196: 39-50$.

Egglishaw, H. J. (1969) : The distribution of benthic invertebrates on substrata in fast-flowing streams. J. Animal Ecol., 38 : 19-33.

Gerson, U. (1982): Bryophytes and invertebrates, p. 291-332. In A. J. E. Sмiтн (ed.), Bryophyte Ecology. Chapman and Hall.

Harrod, J. J. (1964): The distribution of invertebrates on submerged aquatic plants in a chalk stream. J. Anim. Ecol., 33 : 335-348.

Hynes, H. B. N. (1961): The invertebrate fauna of Welsh mountain stream. Arch. Hydrobiol., 57 : 344-388.

Ito, T. and T. HatToRs (1986): Description of a new species of Palaeagapetus (Trichoptera, Hydroptilidae) from northern Japan, with notes on bionomics. Kontyu, 54: 143-151.

Iтo, T. (1988) : Life histories of Palazagapetus ovatus and Eubasilissa regina (Trichoptera) in a spring stream, with special reference to the predator 
-prey relationship. Kontyu, $56: 148-160$.

ITo, T. (1991): Description of a new species of Palaeagapetus from central Japan, with notes on bionomics (Trichoptera, Hydroptilidae). Jpn. J. Ent., 59 : 357-366.

Kato, H. (1992): Utilization of bryophytes by macroinvertebrates in the upper sites of streams. M.Sc. thesis, Shinshu University (in Japanese).

KawaI, T. (ed.) (1990): An Illustrated Book of Aquatic Insects of Japan -4th ed. Tokai Univ. Press (in Japanese).

Maurer, M. A. and M. A. Brusven (1983): Insect abundance and colonization rate in Fontinalis neomexicana (Bryophyta) in an Idaho batholith stream, U.S.A. Hydrobiologia, 98 : 9-15.

McElhone, M. J. and W. Davies. (1983): The influence of rock surface area on the microdistribution and sampling of attached riffle dwelling Trichoptera in Hartley Creek, Alberta. Can. J. Zool., 61: 2300-2304.

Minshall, G. W. (1984) : Aquatic insect-substratum relationships, p. 358-400. In V. H. Resh \& D. M. Rosenberg (eds.), The Ecology of Aquatic Insects. Praeger.

Rооке, J. В. (1984): The invertebrate fauna of four macrophytes in a lotic system. Freshwat. Biol., I4: 507-513.

SoKal, R. R. and F. J. RohlF (1981): Biometry, 2nd ed. W. H. Freeman and Company.

Suren, A. M. (1991): Bryophytes as invertebrate habitat in two New Zealand alpine streams. Freshwat. Biol., 26 : 399-418.

TsudA, M. (1940): Preliminary investigations on fauna within moss in streams. Jpn. J. Limnol., $10: 141-149$ (in Japanese).

Winterbourn, M. J. and C. R. Townsend (1991): Streams and Rivers: One-way Flow Systems, p. 230-242. In R. S. K. BARNES and K. H. MANN (eds.), Fundamentals of Aquatic Ecology -2nd ed., 12. Blackwell Scientific Publications.

(著者：多田満, 国立環境研究所生物圈環境部; 佐 竹研一, 国立環境研究所地球環境研究グループ, テ 305 茨城県つくば市小野川16-2；Mitsuru TADA, Ken'ichi SATAKE, National Institute for Environmental Studies, Onogawa, Tsukuba, Ibaraki 305)

Received: 31 May 1993

Accepted : 7 January 1994 